\title{
ANIMAL REVIEW \\ Methane emissions and growth performance of young Nellore bulls fed crude glycerine- $v$. fibre-based energy ingredients in low or high concentrate diets
}

\author{
J. F. LAGE ${ }^{*}$, E. SAN VITO ${ }^{2}$, R. A. REIS ${ }^{2}$, E. E. DALLANTONIA ${ }^{2}$, L. R. SIMONETTI ${ }^{2}$, \\ I. P. C. CARVALHO ${ }^{3}$, A. BERNDT ${ }^{4}$, M. L. CHIZZOTTI ${ }^{5}$, R. T. S. FRIGUETTO ${ }^{6}$ AND T. T. BERCHIELLI ${ }^{2}$ \\ ${ }^{1}$ Trouw Nutrition Brazil, Bellman, R\&D - Campinas, SP, Brazil \\ ${ }^{2}$ Department of Animal Science, Universidade Estadual Paulista, Júlio de Mesquita Filho, Jaboticabal, SP, Brazil \\ ${ }^{3}$ Trouw Nutrition, R\&D - Boxmeer, Netherlands \\ ${ }^{4}$ Embrapa Pecuária Sudeste, São Carlos, SP, Brazil \\ ${ }^{5}$ Department of Animal Science, Universidade Federal de Viçosa, Viçosa, MG, Brazil \\ ${ }^{6}$ Embrapa Meio Ambiente, Jaguariúna, SP, Brazil
}

(Received 21 April 2015; revised 15 February 2016; accepted 13 April 2016)

\section{SUMMARY}

A total of 70 Nellore bulls ( $18 \pm 3$ months of age) were used to determine the effects of crude glycerine (CG) replacing starch- $v$. fibre-based energy ingredients in low (LC; 0.40 concentrate) or high concentrate (HC; 0.60 concentrate) - on a dry matter (DM) basis - on DM intake (DMI), methane emissions and growth. Ten bulls were slaughtered (reference group) to obtain the carcass gain (CrG). The 60 remaining bulls ( $374 \pm 24 \cdot 5 \mathrm{~kg}$ ) were allocated to a $2 \times 3$ factorial arrangement (two concentrate levels, LC or HC; and three feeding regimes, FR). The FR were: CO - without CG and maize as an ingredient of concentrate; CGM - inclusion of CG (0.10 of DM) replacing maize in the concentrate; and CGSH - inclusion of CG (0.10 of DM) replacing soybean hulls (SH) in the concentrate. Bulls fed LC or HC had similar DMI $(\mathrm{kg} / \mathrm{d})$ and growth. The DMI and average daily gain (ADG) were similar among FR. Concentrate level and FR tended to interact for methane emissions (g) per kg DMI. Bulls fed CGM had a greater $\mathrm{G}: \mathrm{F}$ (g CrG/kg DMI) than those fed CO or CGSH diets. Increasing dietary concentrate $(0 \cdot 40-0 \cdot 60)$ did not affect intake, methane emissions, or growth. Inclusion of CG in diets to replace SH in LC diets tended to decrease methane emissions from animals. When CG replaces $\mathrm{SH}$ in the diets, $\mathrm{CrG}$ and $\mathrm{G}: \mathrm{F}$ (g CrG/kg DMI) are decreased compared with bulls fed CGM.

\section{INTRODUCTION}

Elevated maize prices, the result of increased maize demand for the bioethanol industry, have increased the inclusion of agroindustrial by-products in ruminant diets. Crude glycerine (CG) is a by-product from the biodiesel agroindustry that can be used in ruminant diets, and can account for up to $0 \cdot 10$ of diet dry matter (DM; Parsons et al. 2009; Drouillard 2012) thus decreasing the acetate: propionate ratio in the rumen (Avila et al. 2011; Ramos \& Kerley 2012). Considering the inverse relationship between methane $\left(\mathrm{CH}_{4}\right)$ and propionate production

\footnotetext{
* To whom all correspondence should be addressed. Email: josiane.lage@trouwnutrition.com; josilage@gmail.com
}

(Mitsumori \& Sun 2008), feeding CG may reduce $\mathrm{CH}_{4}$ emissions from ruminants.

Almost all studies have reported the use of high concentrate $(\mathrm{HC})$ diets with CG replacing rapidly fermentable starch. Schroder \& Sudekum (1999) suggested that CG could replace up to $0 \cdot 10$ of readily fermentable starches: according to these authors, the energetic value of a high-starch concentrate diet $(0 \cdot 60$ concentrate) was approximately 0.85 compared with that of a low-starch concentrate diet. Propionate production is typically greater in concentrate-fed animals, and thus there may be less opportunity to improve energetic efficiency when glycerine is combined with concentrates compared with feeding with forage (Drouillard 2008). 
It was hypothesized that providing CG in conjunction with soybean hulls in low concentrate (LC) diets to beef cattle should reduce $\mathrm{CH}_{4}$ emissions in comparison with bulls fed starch-based energy diets. The objective of the current study was to evaluate the effects of CG in combination with starch- $v$. fibrebased energy ingredients in $\mathrm{LC}$ and $\mathrm{HC}$ diets on $\mathrm{CH}_{4}$ emissions and growth performance of beef cattle.

\section{MATERIALS AND METHODS}

\section{Experimental design and diets}

The experiment was conducted at the Sao Paulo State University (UNESP, Jaboticabal, SP, Brazil) and humane animal care and handling procedures were followed according to the guidelines of Sao Paulo State University. Pre-slaughter handling was in accordance with good animal welfare practices, and slaughter procedures followed the Sanitary and Industrial Inspection Regulation for Animal Origin Products (Brazil 1997).

Seventy 18-month-old Nellore bulls were used in the experiment. Sixty young bulls, housed in individual pens with automatic drinkers, were weighed after a 16-h solid food fast to obtain reduced body weight (BW) values $(374 \pm 24.5 \mathrm{~kg})$. The bulls were allocated by BW into a $2 \times 3$ factorial arrangement (two concentration levels (CL), 0.40 or 0.60 ; and three feeding regimes) with ten bulls per treatment. Bulls were allowed to acclimatize for 21 days to experimental housing and diets. After the acclimatization period, bulls were evaluated for 94 days to obtain DM intake (DMI), $\mathrm{CH}_{4}$ emissions, blood parameters and growth performance.

Young bulls were assigned randomly to one of the following experimental diets: CO - without CG, with maize as the concentrate ingredient; CGM - inclusion of CG $(0 \cdot 10$ of DM) replacing maize in the concentrate; and CGSH - inclusion of CG (0.10 of DM) replacing soybean hulls in the concentrate, offered at two CL $(0 \cdot 40$ or $0 \cdot 60)$. These levels were representative of diets with $>0.50$ of roughage and $>0.50$ of concentrate, commonly used in the finishing phase of beef cattle in Brazil. Crude glycerine was acquired from a soybean oil-based biodiesel production company (ADM, Rondonópolis, Brazil; 0.80 glycerol, 0.02 ether extract, 0.05 ash and 0.12 water). Maize silage was the only source of roughage and the concentrates comprised ground maize or soybean hulls, soybean meal, urea/ammonium sulphate and a mineral mixture. Soybean meal was used as an alternative protein source, and a mixture of urea and ammonium sulphate was used to adjust the diet crude protein $(\mathrm{CP})$ content. All diets were balanced to provide $14 \cdot 4 \pm$ 0.21 CP (Valadares Filho et al. 2006). The proportions of ingredients and chemical composition of the experimental diets are presented in Table 1.

\section{Dry matter intake}

Cattle were fed twice daily at 08.00 and $16.00 \mathrm{~h}$ and feed refusals were recorded daily for each pen at $06.00 \mathrm{~h}$ for 115 days (acclimatization plus experimental period). Amounts of feed offered to bulls were calculated according to previous DMI and adjustments were made when needed to ensure refused feed was always between 0.05 and $0 \cdot 10$ of daily intake. Feed refusals were collected, weighed and sampled daily for subsequent analysis. To estimate DMI, samples of individual ingredients and feed refusals from each animal were first composited weekly and then batched every month. Feed samples were frozen (composite of daily samples) at $-18{ }^{\circ} \mathrm{C}$. For proximate analysis, samples of ingredients and feed refusals were thawed and dried at $55^{\circ} \mathrm{C}$ for $72 \mathrm{~h}$. Samples were then ground in a Wiley mill (Thomas Scientific, Swedesboro, NJ, USA) to pass through a 1-mm screen and analysed for DM and ether extract (AOAC 1990). Nitrogen content was determined by combustion (Leco Instruments Inc., method 976.06, AOAC 1990) and multiplied by $6 \cdot 25$ to obtain CP and neutral detergent fibre (NDF) was determined by the method of Van Soest et al. (1991) using Ankom bags (Ankom Technology Corp., Fairport, NY, USA).

\section{Methane measurements}

Methane emissions were measured using the sulphur hexafluoride $\left(\mathrm{SF}_{6}\right)$ tracer technique (Johnson et al. 1994), where each animal was sampled daily for 5 consecutive days, beginning at 87 days of feeding. Thirty-six docile bulls (six treatment replicates) were fitted with gas collection halters at 10 days before methane sampling to allow bulls to adapt to halters and thus facilitate sampling. Brass permeation tubes filled with $\mathrm{SF}_{6}$ with known release rates were administered orally to each of the 36 bulls $72 \mathrm{~h}$ before methane sampling to allow the tracer gas to equilibrate in the rumen. The release rate of the gas from a permeation tube is known before its insertion into the rumen. Before administration, the permeation 
Table 1. Diet composition (dry matter basis)

\begin{tabular}{|c|c|c|c|c|c|c|}
\hline \multirow[b]{2}{*}{ Item } & \multicolumn{3}{|c|}{ Low concentrate $(0 \cdot 40)$} & \multicolumn{3}{|c|}{ High concentrate $(0 \cdot 60)$} \\
\hline & $\mathrm{CO}$ & CGM & CGSH & $\mathrm{CO}$ & CGM & CGSH \\
\hline \multicolumn{7}{|l|}{ Ingredient (proportion of DM) } \\
\hline Maize silage & $0 \cdot 60$ & $0 \cdot 60$ & $0 \cdot 60$ & $0 \cdot 40$ & $0 \cdot 40$ & $0 \cdot 40$ \\
\hline Maize & $0 \cdot 26$ & $0 \cdot 16$ & - & $0 \cdot 46$ & $0 \cdot 36$ & - \\
\hline Soybean meal & $0 \cdot 10$ & $0 \cdot 10$ & $0 \cdot 10$ & $0 \cdot 10$ & $0 \cdot 10$ & $0 \cdot 10$ \\
\hline Soybean hulls & - & - & $0 \cdot 16$ & - & - & $0 \cdot 37$ \\
\hline Crude glycerine & - & $0 \cdot 10$ & $0 \cdot 10$ & - & $0 \cdot 10$ & $0 \cdot 10$ \\
\hline Urea & $0 \cdot 007$ & $0 \cdot 01$ & $0 \cdot 008$ & $0 \cdot 006$ & $0 \cdot 009$ & 0.004 \\
\hline Mineral pre-mix* & 0.03 & 0.03 & 0.03 & 0.03 & 0.03 & $0 \cdot 03$ \\
\hline \multicolumn{7}{|l|}{ Component compositiont (g/kg) } \\
\hline Dry matter & $576 \cdot 0$ & $579 \cdot 0$ & $586 \cdot 0$ & $670 \cdot 8$ & $673 \cdot 8$ & $689 \cdot 0$ \\
\hline Crude protein & $143 \cdot 0$ & $147 \cdot 0$ & $146 \cdot 0$ & $144 \cdot 5$ & $142 \cdot 0$ & $141 \cdot 0$ \\
\hline Neutral detergent fibre & $301 \cdot 4$ & $285 \cdot 3$ & $376 \cdot 0$ & 251.9 & $235 \cdot 9$ & $429 \cdot 5$ \\
\hline Ether extract & $31 \cdot 3$ & $30 \cdot 1$ & $29 \cdot 2$ & $31 \cdot 8$ & $30 \cdot 5$ & $28 \cdot 3$ \\
\hline Non-fibre carbohydratesł & $470 \cdot 0$ & $494 \cdot 6$ & $401 \cdot 4$ & $539 \cdot 3$ & $554 \cdot 8$ & $354 \cdot 6$ \\
\hline Metabolizable energy (MJ/kg) & $107 \cdot 1$ & $106 \cdot 3$ & $104 \cdot 6$ & $112 \cdot 1$ & $111 \cdot 7$ & $108 \cdot 8$ \\
\hline
\end{tabular}

$\mathrm{CO}$, maize without crude glycerine; CGM, crude glycerine replacing maize; $\mathrm{CGSH}$, crude glycerine replacing soybean hulls.

* Trace mineral mix contained: calcium, 210 g; phosphorus, 20 g; sulphur, 37 g; sodium, 80 g; copper, 490 mg; manganese,

$1.424 \mathrm{mg}$; zinc, 1.830 mg; iodine, $36 \mathrm{mg}$; cobalt, $29 \mathrm{mg}$; selenium, $9 \mathrm{mg}$; fluorine max., $333 \mathrm{mg}$.

+ Dry matter basis. All components were analysed. Metabolizable energy was calculated as Digestible Energy $\times 0 \cdot 82$.

₹ Non-fibre carbohydrates $=100$ - (crude protein + ether extract + ash + neutral detergent fibre).

tubes were maintained in a water bath at $39{ }^{\circ} \mathrm{C}$ for 8 weeks in the laboratory and weighed weekly. The bulls were fitted with gas collection halters connected to pre-evacuated polyvinyl chloride canisters designed to fill halfway over $24 \mathrm{~h}$. Sampling started at $06.00 \mathrm{~h}$ daily (one by one), when each bull was moved individually to the handling pens at the management centre to facilitate sampling. The collection canisters were located above each animal to reduce the risk of equipment damage, and were connected to the halter by airline flexible-coil tubing. The canisters were removed from the animals at 24-h collection intervals and the pressure was measured. For this technique, a two-stage vacuum pump and a digital manometer were used with a scale from 0 to $203 \mathrm{kPa}$. This allowed measurement of the initial and final pressure of each canister during the collection period. If final pressure was out of the expected range, the halter was replaced in a maximum of $15 \mathrm{~min}$. If final pressure was above the expected range, the halter might have been blocked or disconnected; if the final pressure was below the expected range, there was possibly a leak in the system. In both situations, a new halter was placed on the animal with an average absorption rate within the stipulated range (half full in $24 \mathrm{~h}$ ). After sampling (which took approximately 15 min per animal to remove animals from the pen and change the canister), each animal was returned to their original pen for feeding. A minimum of three samples (final pressure with expected range) from each animal was required to include in data analysis. The pressure readings were recorded and the canisters were pressurized using pure nitrogen gas $\left(\mathrm{N}_{2}\right)$. Two samples of ambient air were collected per day in the feedlot to determine background concentrations of $\mathrm{CH}_{4}$ and $\mathrm{SF}_{6}$. These values were subtracted from the bull values to calculate the net output in their expired breath. Concentrations of $\mathrm{CH}_{4}$ and $\mathrm{SF}_{6}$ were determined at the EMBRAPA Environment laboratory, located in Jaguariúna, Sao Paulo State, Brazil, by a gas chromatograph HP6890 (Agilent, Delaware, USA), equipped with flame ionization detector at $280{ }^{\circ} \mathrm{C}$, column megabore $(0.53 \mathrm{~mm} \times 30 \mathrm{~m} \times 15 \mu \mathrm{m})$ Plot $\mathrm{HP}-\mathrm{Al} / \mathrm{M}$ (for $\mathrm{CH}_{4}$ ), electron capture detector at $300{ }^{\circ} \mathrm{C}$ and column megabore $(0.53 \mathrm{~mm} \times 30 \mathrm{~m} \times 25.0 \mu \mathrm{m}) \mathrm{HP}$ MolSiv (for $\mathrm{SF}_{6}$ ), with two loops of $0.5 \mathrm{~cm}^{3}$ maintained at $80{ }^{\circ} \mathrm{C}$ attached to two six-way valves. The gas chromatography column was maintained at $50{ }^{\circ} \mathrm{C}$ during the analysis and heated to $150{ }^{\circ} \mathrm{C}$ for about $15 \mathrm{~min}$ 
for cleaning purposes. Soon after the collection period and prior to the determination of $\mathrm{CH}_{4}$ and $\mathrm{SF}_{6}$, the canisters were pressurized to between 1.3 and 1.5 psi (g) using special nitrogen $5 \cdot 0$, and then readings of the initial and final dilution pressures were taken with a portable digital manometer $( \pm 0 \cdot 01)$, certified for reading range from -1 to +2 bar (g) (Druck, model DPI705), in order to obtain the dilution factor. Calibration curves were established using standard gases certified by the White Martins development laboratory, with the concentration for $\mathrm{CH}_{4}$ in ppm $(5 \pm 0 \cdot 25,10 \pm 0.16$ and $19 \pm 0.65 \mathrm{ppm})$ and for $\mathrm{SF}_{6}$ in ppt $(34 \pm 9 \cdot 0,91 \pm 9 \cdot 0$ and $978 \pm 98 \cdot 0 \mathrm{ppt})$, according to Westberg et al. (1998). Methane emission rate was calculated as follows:

$$
\mathrm{QCH}_{4}=\mathrm{QSF}_{6} \times\left[\mathrm{CH}_{4}\right] /\left[\mathrm{SF}_{6}\right]
$$

where $\mathrm{QCH}_{4}$ is the emission rate of methane in litres/h, $\mathrm{QSF}_{6}$ is the known release rate of $\mathrm{SF}_{6}$ from the permeation tube, and $\mathrm{CH}_{4}$ and $\mathrm{SF}_{6}$ are the measured concentrations in the canister. Methane emissions (g/bull/ day) and $\mathrm{g} \mathrm{CH}_{4} / \mathrm{kg}$ DMI (g/kg) were calculated by dividing the daily $\mathrm{CH}_{4}$ output of each animal by daily intake (during methane sampling) and methane emissions (g/bull/day) in relation to $\mathrm{kg}$ of average daily gains (ADG) and $\mathrm{kg}$ of carcass gain ( $\mathrm{CrG}$ ), both throughout the entire experimental period. The variable $\mathrm{CH}_{4}(\mathrm{~g} / \mathrm{kg} \mathrm{CrG})$ is the weight of methane (g) produced each day per kg of daily $\mathrm{CrG}$.

\section{Growth and performance recording}

At the beginning of the trial ( 0 day-after 21 days of acclimatization period), all bulls were weighed after the 16-h solid fast and before the first feeding in the morning. The ADG was obtained by weighing animals at the beginning and end of the experiment (94 days), always after a 16-h solid fast. After 94 days of feeding, all the bulls were slaughtered at a commercial beef plant. To obtain $\mathrm{CrG}$, ten bulls were slaughtered $(384 \pm 41 \cdot 1 \mathrm{~kg})$ and served as the reference group at the beginning of the experiment (day 0) to obtain the initial dressing percentage $(51.9 \%)$, which was used to estimate the initial carcass weight (CWi) to obtain the $\mathrm{CrG}$ and $\mathrm{CrG}$ in relation to the ADG (CrG/ADG) at the end of experiment. The dressing percentage (DP) of reference group was used in conjunction with initial BW (day 0) of 60 bulls to estimate the initial CWi of these 60 bulls using the equation: $\mathrm{CWi}=(\mathrm{BWi} \times \mathrm{DP}$ of reference group $) / 100$. At the end of experiment, the 60 bulls were slaughtered and the final carcass weight (CWf) was recorded for each animal, thus $\mathrm{CrG}=(\mathrm{CWf}-\mathrm{CWi} / \mathrm{d}$ of feeding $)$.

\section{Blood parameters}

Jugular vein blood samples were taken from all bulls after the 16-h solid fast and before the first feeding at 0,59 and 94 days. Blood samples were collected in commercial blood collection Vacutainer tubes $(10 \mathrm{ml}$; BD Biosciences, Franklin Lakes, NJ) and EDTA-coated glass Vacutainer tubes $(10 \mathrm{ml}$; BD Biosciences, Franklin Lakes, NJ). They were placed on ice and centrifuged at $2500 \times \mathbf{g}$ for $20 \mathrm{~min}$ at $4{ }^{\circ} \mathrm{C}$; the resulting serum or plasma was decanted and stored at $-20{ }^{\circ} \mathrm{C}$ until laboratory analysis. Fasting plasma samples were analysed for glucose (Glucose Liquiform Vet Kit, Labtest Diagnostica S.A., Lagoa Santa, Brazil) and serum samples were analysed for insulin (ADVIA Centaur CP Insulina - IRI, manufactured in Japan by Kyowa Medex Co., Ltd. For Siemens Healthcare Diagnostics Inc., Tarrytown, New York, USA) using commercial kits.

\section{Carcass characteristics}

Ultrasound measures of rib fat thickness (RFT) and loin muscle area (LMA) between the 12th and 13th rib were obtained on days $0,27,59$ and 94 for each animal using an Aloka $500 \mathrm{~V}$ real time ultrasound machine (Hitachi Aloka Medical, Ltd, Tokyo, Japan) equipped with a $17 \cdot 2-\mathrm{cm}, 3 \cdot 5-\mathrm{MHz}$ linear transducer (Greiner et al. 2003). Images were taken by a technician certified by the Ultrasound Guideline Council and images were interpreted using the software Biosoft Toolbox ${ }^{\circledR}$ II for Beef (Biotronics, Inc., Ames, lowa, USA).

\section{Statistical analysis}

All data were analysed using the SAS PROC MIXED procedure (SAS Inst. Inc., Cary, North Carolina, USA). The model tested the fixed effects of the $\mathrm{CL}$, FR (i.e., without CG, CG plus maize, and CG plus soybean hulls) and the interaction of $\mathrm{CL}$ and FR. For all data, the animal was the experimental unit and was included in the model as a random effect. When the interaction term was not significant, it was removed from the model. The ultrasound measurements and serum concentrations of glucose and insulin were analysed as repeated measurements in time using the MIXED procedure. This model included 
the effects of the $C L, F R$, time and $C L \times F R \times$ time interactions as fixed effects and the animals as random effects. The best (co)variance matrix was chosen based on Akaike's Information Criteria. Least-squares means were generated for main-effects and significant interactions and compared (significance was set at $P \leqslant 0.05$ ) using Tukey's test. For all variables, $P$-values between 0.05 and 0.10 are considered tendencies.

\section{RESULTS}

Bulls fed LC or HC diets had similar DMI $(P=0.886$; Table 2). Because of the similarity in the DMI, bulls had a similar ADG $(P=0.962)$, final BW $(P=0.597)$ and G : F (g ADG/kg DMl; $P=0.781 ;$ Table 3). Differences in DMl were not observed $(P=0.887$; Table 2) among the FR and animals showed similar ADG $(P=0.985)$, final BW $(P=0.970)$, and $\mathrm{G}: \mathrm{F}$, $\mathrm{g}$ ADG $/$ kg DMI $(P=0 \cdot 853$; Table 3$)$.

The daily methane emissions (g/bull/day; $P=0.985$ ) did not differ significantly between the concentrate level (Table 2); nor did g/bull/day in relation to $\mathrm{kg}$ of DMI $(P=0.759), \mathrm{g} /$ bull/day in relation to $\mathrm{kg}$ of ADG $(P=0.234)$, and $\mathrm{g} / \mathrm{bull} / \mathrm{day}$ in relation to $\mathrm{kg}$ of $\mathrm{CrG}$ $(P=0.791$; Table 2). No differences were observed in daily methane emissions (g/bull/day; $P=0.854)$ in relation to $\mathrm{kg}$ of ADG $(P=0.778)$ or $\mathrm{kg}$ of $\mathrm{CrG}(P=$ $0 \cdot 634)$ among the FR. However, there was a tendency for an interaction between $C L$ and $F R$ for methane emissions (g/bull/day) per $\mathrm{kg}$ of $\mathrm{DMI}(P=0 \cdot 067)$. Bulls fed CG in the HC diet had a tendency to produce greater methane emissions ( $\mathrm{g} / \mathrm{kg} \mathrm{DMl}$ ) than bulls fed $\mathrm{HC}$ diets without CG.

Bulls fed CG as a replacement for maize in LC diets also had a tendency to produce greater methane emissions ( $\mathrm{g} / \mathrm{kg} \mathrm{DMl})$ than bulls fed $\mathrm{HC}$ diets without CG $(P=0 \cdot 067)$. Bulls fed CG as a replacement for soybean hulls in LC diets had similar methane emissions (g/bull/day/kg DMI) to bulls fed starch-based ingredients at $\mathrm{HC}$ with or without CG. In addition, these bulls had a tendency to emit less methane (g/bull/day/kg DMI) than bulls fed fibre-based energy ingredients in $\mathrm{HC}$ diets with CG $(P=0 \cdot 067)$.

The $\mathrm{CrG}, \mathrm{CrG} / \mathrm{ADG}$, and $\mathrm{G}$ : $\mathrm{F}$ (g CrG/kg DMl) were similar $(P>0 \cdot 10$; Table 3$)$ in bulls fed LC or $\mathrm{HC}$ diets, and bulls had similar blood glucose concentrations ( $P=0 \cdot 107$; Fig. 1$)$, insulin $(P=0 \cdot 822$; Fig. 2$)$, and insulin: glucose ratios $(P=0.990 ;$ Table 4$)$. Differences were not detected for $\mathrm{CL} \times \mathrm{FR} \times$ time $(P=0.25 ; P=0.93 ; P=0.44 ;$ data not shown $)$ in the blood. Furthermore, bulls did not differ in LMA $(P=0 \cdot 96)$ or RFT $(P=0 \cdot 18$; Table 5$)$.

Although differences in ADG were not identified, bulls fed diets with CG as a replacement for starchbased energy ingredients had a tendency to obtain greater ( $P=0.094$; Table 3) CrG than bulls fed diets with CG as a replacement for fibre-based energy ingredients. Bulls fed diets with CG as a replacement for starch-based energy ingredients had a tendency $(P=0 \cdot 108)$ to achieve greater CrG/ADG than bulls fed the CO diet or diets with CG replacing fibrebased energy ingredients. Because of similar DMI but greater $\mathrm{CrG}$, bulls fed diets CGM had better $(P<$ 0.001) G : F (g CrG/kg DMI) than bulls fed the CO diet because bulls fed diets without CG had greater $\mathrm{G}$ : F (g CrG/kg DMI) than bulls fed diets with CGSH.

Bulls fed CG as a replacement for maize had similar serum glucose concentrations to bulls fed diets without CG and maize. However, when CG replaced fibre-based ingredients, serum glucose concentrations increased ( $P=0 \cdot 004$; Table 4) more than when bulls were fed diets without CG plus maize.

No differences were observed among the $F R$ in insulin $(P=0 \cdot 128)$ or the insulin: glucose ratio $(P=$ $0 \cdot 149$ ) (Table 4). The interaction between time, $\mathrm{CL}$ and FR were not significant for insulin $(P=0.934)$ or glucose $(P=0 \cdot 226)$. However, a significant effect of time (sampling period) was detected for glucose $(P=$ 0.028; Fig. 1), insulin ( $P=0.039$; Fig. 2) and the insulin: glucose ratio $(P=0.031 ;$ Table 4$)$. Serum glucose concentrations on day 94 were less than those on day $0(73 \pm 1 \cdot 6 \mathrm{v} .78 \pm 1 \cdot 1 \mathrm{mg} / \mathrm{dl}$, respectively; $P=0.061)$ and day $59(78 \pm 2.1 \mathrm{mg} / \mathrm{dl} ; P=0.049)$, but did not differ $(P=0.991)$ between days 0 and 59 (Fig. 1). The serum insulin concentrations on day 94 were greater than those on day $0(6 \pm 1 \cdot 0 \mathrm{~V} \cdot 2 \cdot 0 \pm$ $1.03 \mu$ international unit $(\mathrm{IU}) / \mathrm{ml} ; P=0.041)$, but did not differ $(P=0.739)$ between days 94 and $59(5 \pm$ $1 \cdot 0 \mu \mathrm{lU} / \mathrm{ml})$.

The interaction between time, $C L$ and FR were not significant for LMA $(P=0.980)$ or RFT $(P=0.995)$. Bulls fed fibre-based energy ingredients had a smaller $(P=0.019)$ LMA than bulls fed diets without or with CG as a replacement for maize (Table 5). Unlike LMA, no differences were observed for RFT $(P=0 \cdot 110)$ among the FR (Table 5).

\section{DISCUSSION}

According to Forbes (2007), increasing the level of supplementation with concentrates often causes a 
Table 2. Effect of crude glycerine replacing maize or soybean hulls in low-or high-concentrate diets on methane $\left(\mathrm{CH}_{4}\right)$ emissions from cattle

\begin{tabular}{|c|c|c|c|c|c|c|c|c|c|c|}
\hline \multirow[b]{2}{*}{ Item } & \multicolumn{2}{|c|}{ Concentrate level (CL) } & \multirow[b]{2}{*}{ S.E.M. } & \multicolumn{3}{|c|}{ Feeding regimes (FR) } & \multirow[b]{2}{*}{ S.E.M. } & \multicolumn{3}{|c|}{$P$-value } \\
\hline & Low $(0 \cdot 40)$ & High $(0 \cdot 60)$ & & $\mathrm{CO}$ & CGM & $\mathrm{CGSH}$ & & $\mathrm{CL}$ & FR & $\mathrm{CL} \times \mathrm{FR}$ \\
\hline DMI (kg/d) & $9 \cdot 2$ & $9 \cdot 2$ & $0 \cdot 33$ & $9 \cdot 1$ & $9 \cdot 1$ & $9 \cdot 4$ & $0 \cdot 53$ & $0 \cdot 886$ & $0 \cdot 887$ & 0.921 \\
\hline $\mathrm{CH}_{4}$ (g/bull/day) & 174 & 173 & $19 \cdot 9$ & 161 & 189 & 171 & $32 \cdot 8$ & 0.985 & $0 \cdot 854$ & $0 \cdot 489$ \\
\hline $\mathrm{CH}_{4}(\mathrm{~g} / \mathrm{bull} /$ day/kg DMl) & $20 \cdot 8$ & $21 \cdot 2$ & $0 \cdot 80$ & $19 \cdot 3$ & $22 \cdot 3$ & $21 \cdot 4$ & 0.98 & 0.759 & $0 \cdot 096$ & $0 \cdot 067$ \\
\hline $\mathrm{CH}_{4}$ (g/bull/day/kg ADG) & 139 & 127 & $13 \cdot 2$ & 124 & 146 & 130 & $21 \cdot 1$ & 0.234 & 0.778 & $0 \cdot 603$ \\
\hline $\mathrm{CH}_{4}$ (g/bull/day/kg CrG) & 189 & 185 & $9 \cdot 3$ & 181 & 185 & 195 & $11 \cdot 4$ & $0 \cdot 791$ & $0 \cdot 634$ & $0 \cdot 508$ \\
\hline
\end{tabular}

$\mathrm{CO}$, maize without crude glycerine; CGM, crude glycerine replacing maize; $\mathrm{CGSH}$, crude glycerine replacing soybean hulls; $\mathrm{DMI}$, dry matter intake; $\mathrm{CL}$, concentrate level effect; $\mathrm{FR}$, feeding regime effect; $\mathrm{CL} \times \mathrm{FR}$, concentrate level and feeding regime interaction effect; $\mathrm{CrG}$, carcass gain.

Table 3. Effects of the addition of crude glycerine to replace maize or soybean hulls in low- or high-concentrate diets on cattle growth performance and feed efficiency

\begin{tabular}{|c|c|c|c|c|c|c|c|c|c|c|}
\hline \multirow[b]{2}{*}{ Item } & \multicolumn{2}{|c|}{ Concentrate level $(\mathrm{CL})$} & \multirow[b]{2}{*}{ S.E.M. } & \multicolumn{3}{|c|}{ Feeding regimes (FR) } & \multirow[b]{2}{*}{ S.E.M. } & \multicolumn{3}{|c|}{$P$-value } \\
\hline & Low $(0 \cdot 40)$ & High $(0 \cdot 60)$ & & $\mathrm{CO}$ & CGM & $\mathrm{CGSH}$ & & $\mathrm{CL}$ & $F R$ & $\mathrm{CL} \times \mathrm{FR}$ \\
\hline Final BW (kg) & 501 & 497 & $11 \cdot 7$ & 496 & 499 & 502 & $18 \cdot 7$ & 0.597 & 0.970 & $0 \cdot 697$ \\
\hline ADG (kg/d) & $1 \cdot 4$ & $1 \cdot 4$ & $0 \cdot 07$ & $1 \cdot 4$ & $1 \cdot 4$ & $1 \cdot 4$ & $0 \cdot 11$ & 0.962 & 0.985 & $0 \cdot 286$ \\
\hline $\mathrm{CrG}(\mathrm{g} / \mathrm{d})$ & $939 \cdot 9$ & $932 \cdot 5$ & $0 \cdot 02$ & $928 \cdot 3$ & $988 \cdot 3$ & $892 \cdot 0$ & 0.03 & $0 \cdot 837$ & $0 \cdot 094$ & $0 \cdot 647$ \\
\hline $\mathrm{CrG} / \mathrm{ADG}(\%)^{*}$ & 70 & 69 & $2 \cdot 1$ & 66 & 75 & 66 & $3 \cdot 4$ & $0 \cdot 652$ & $0 \cdot 108$ & $0 \cdot 486$ \\
\hline G:F (g ADG/kg DMI)† & $147 \cdot 3$ & $148 \cdot 7$ & $0 \cdot 01$ & $150 \cdot 2$ & $151 \cdot 1$ & $142 \cdot 6$ & 0.01 & 0.781 & $0 \cdot 853$ & $0 \cdot 153$ \\
\hline G:F (g CrG/kg DMI)‡ & $103 \cdot 6$ & $103 \cdot 7$ & $0 \cdot 01$ & $103 \cdot 9$ & $111 \cdot 2$ & $96 \cdot 0$ & 0.01 & 0.983 & $<0 \cdot 001$ & $0 \cdot 387$ \\
\hline
\end{tabular}

$\mathrm{CO}$, maize without crude glycerine; CGM, crude glycerine replacing maize; $\mathrm{CGSH}$, crude glycerine replacing soybean hulls; $\mathrm{BW}$, body weight; $\mathrm{ADG}$, average daily gain; $\mathrm{CrG}$, carcass gain; $\mathrm{DMl}$, dry matter intake; $\mathrm{CL}$, concentrate level effect; $\mathrm{FR}$, feeding regime effect; $\mathrm{CL} \times \mathrm{FR}$, concentrate level and feeding regime interaction effect; $\mathrm{CrG}$, carcass gain.

* Carcass gain in relation to average daily gain.

+ Gain to feed ratio, g average daily gain/kg DMI.

₹ Gain to feed ratio, g carcass gain $/ \mathrm{kg}$ DMI.

decline in the rate of forage digestion in the rumen, impairing the DMI. Generally, the evident drop in DMI happens following the introduction of a diet with increased concentrate proportion (Holtshausen et al. 2013). Differences were not observed in DMI between $\mathrm{CL}$ and similar results were reported by Pina et al. (2009) who found no effect of $0 \cdot 20$ and 0.40 of concentrate in DMI in diets for Nellore.

The results concerning DMI between FR are consistent with those obtained in other studies, suggesting CG can be included in feed up to $0 \cdot 10$ of DM by replacing rapidly fermentable starch for beef cattle finished in feedlots, without reducing intake or performance (Pyatt et al. 2007; Parsons et al. 2009; Drouillard 2012; Bartoň et al. 2013). The NDF concentration in the experimental diets increased when soybean hulls were included in the concentrate. In the present study, it was hypothesized that the inclusion of CG as a replacement for fibre-based energy ingredients would decrease DMI, possibly because glycerine in the rumen can reduce cellulolytic activity of ruminal bacteria, thereby decreasing fibre digestibility (Roger et al. 1992; Abo El-Nor et al. 2010). However, the inclusion of CG in fibre-based diets did not affect animal DMI, possibly because the soybean hulls rapidly escaped the rumen due to their small feed particle size (Mertens 1997). The partial dietary replacement of rapidly fermentable starch with CG $(0 \cdot 10$ of DM) did not affect the feed conversion ratio in relation to ADG (Bartoň et al. 2013).

According to Johnson \& Johnson (1995) and Yan et al. (2000), the DMl increase may be attributable to an increased digestive outflow rate from the 


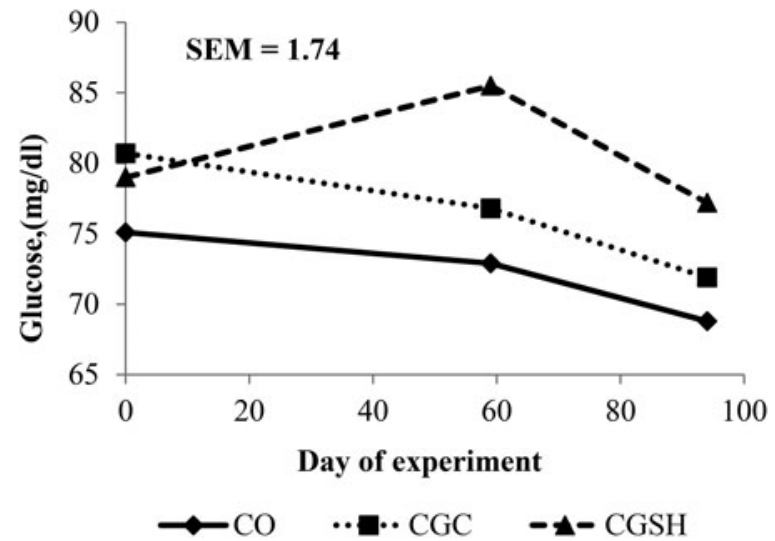

Fig. 1. Glucose serum concentrations of young bulls fed diets: CO, maize without crude glycerine; CGM, crude glycerine replacing maize; $\mathrm{CGSH}$, crude glycerine replacing soybean hulls at low or high concentrate diets during 94days of the experiment. Significant effects of time $(P=0.028)$ and FR $(P=0.004)$ but not for $\mathrm{CL}(P=0.107)$ and $\mathrm{CL} \times \mathrm{FR}$ interaction $(P=0.574)$ were detected.

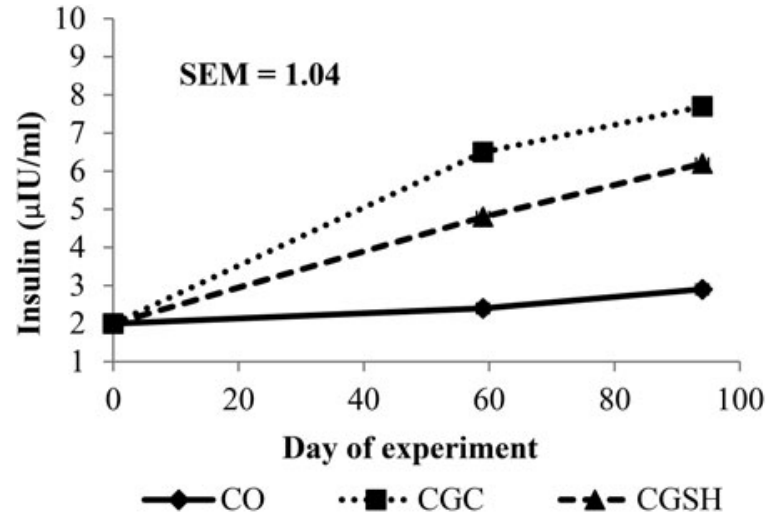

Fig. 2. Insulin serum concentrations of young bulls fed diets: $\mathrm{CO}$, maize without crude glycerine; CGM, crude glycerine replacing maize; $\mathrm{CGSH}$, crude glycerine replacing soybean hulls at low or high concentrate diets during 94 days of the experiment. Significant effects of time $(P=$ $0.039)$ but not for FR $(P=0.128), \mathrm{CL}(P=0.822)$ and $\mathrm{CL} \times$ FR interaction $(P=0.636)$ were detected.

Table 4. Effect of crude glycerine replacing maize or soybean hulls in low or high concentrate diets on serum glucose and insulin concentrations from cattle

\begin{tabular}{|c|c|c|c|c|c|c|c|c|c|c|c|c|}
\hline \multirow[b]{2}{*}{ Item } & \multicolumn{2}{|c|}{ Concentrate level (CL) } & \multirow[b]{2}{*}{ S.E.M. } & \multicolumn{3}{|c|}{ Feeding regimes (FR) } & \multirow[b]{2}{*}{ S.E.M. } & \multicolumn{5}{|c|}{$P$-value } \\
\hline & $\operatorname{Low}(0 \cdot 40)$ & High $(0 \cdot 60)$ & & $\mathrm{CO}$ & CGM & $\mathrm{CGSH}$ & & $\mathrm{T}$ & $\mathrm{CL}$ & $\mathrm{FR}$ & $\mathrm{CL} \times \mathrm{FR}$ & $\mathrm{T} \times \mathrm{CL} \times \mathrm{FR}$ \\
\hline $\begin{array}{l}\text { Glucose } \\
(\mathrm{mg} / \mathrm{dl})\end{array}$ & 75 & 78 & $1 \cdot 4$ & 72 & 77 & 81 & $1 \cdot 7$ & $0 \cdot 028$ & $0 \cdot 107$ & $0 \cdot 004$ & $0 \cdot 574$ & $0 \cdot 226$ \\
\hline $\begin{array}{l}\text { Insulin } \\
(\mu \mathrm{IU} / \mathrm{ml})\end{array}$ & $4 \cdot 2$ & $3 \cdot 9$ & $0 \cdot 84$ & 3 & 5 & 4 & $1 \cdot 1$ & $0 \cdot 039$ & $0 \cdot 822$ & $0 \cdot 128$ & $0 \cdot 636$ & $0 \cdot 934$ \\
\hline $\begin{array}{l}\text { Insulin : } \\
\text { glucose }\end{array}$ & 5 & 5 & $1 \cdot 1$ & 3 & 7 & 6 & $1 \cdot 4$ & $0 \cdot 031$ & $0 \cdot 990$ & $0 \cdot 149$ & $0 \cdot 468$ & $0 \cdot 541$ \\
\hline
\end{tabular}

$\mathrm{CO}$, maize without crude glycerine; CGM, crude glycerine replacing maize; $\mathrm{CGSH}$, crude glycerine replacing soybean hulls; $\mathrm{T}$, time effect; $\mathrm{CL}$, concentrate level effect; $\mathrm{FR}$, feeding regime effect; $\mathrm{CL} \times \mathrm{FR}$, concentrate level and feeding regime interaction effect; $\mathrm{T} \times \mathrm{CL} \times \mathrm{FR}$, time, concentrate level and feeding regime interaction.

Table 5. Effect of crude glycerine replacing maize or soybean hulls in low or high concentrate diets on cattle tissue evaluated through ultrasound

\begin{tabular}{|c|c|c|c|c|c|c|c|c|c|c|c|c|}
\hline \multirow[b]{2}{*}{ Item } & \multicolumn{2}{|c|}{ Concentrate level (CL) } & \multirow[b]{2}{*}{ S.E.M. } & \multicolumn{3}{|c|}{ Feeding regimes (FR) } & \multirow[b]{2}{*}{ S.E.M. } & \multicolumn{5}{|c|}{$P$-value } \\
\hline & Low $(0 \cdot 40)$ & High $(0 \cdot 60)$ & & $\mathrm{CO}$ & CGM & $\mathrm{CGSH}$ & & $\mathrm{T}$ & $\mathrm{CL}$ & $\mathrm{FR}$ & $\mathrm{CL} \times \mathrm{FR}$ & $\mathrm{T} \times \mathrm{CL} \times \mathrm{FR}$ \\
\hline LMA (cm) & $74 \cdot 0$ & $74 \cdot 1$ & $0 \cdot 76$ & 74.9 & $75 \cdot 4$ & $71 \cdot 9$ & 0.93 & $<0 \cdot 001$ & 0.968 & $0 \cdot 019$ & $0 \cdot 415$ & 0.980 \\
\hline RFT (mm) & $4 \cdot 2$ & $4 \cdot 1$ & $0 \cdot 10$ & $4 \cdot 2$ & $4 \cdot 3$ & $3 \cdot 9$ & $0 \cdot 12$ & $<0 \cdot 001$ & $0 \cdot 182$ & $0 \cdot 110$ & $0 \cdot 391$ & 0.995 \\
\hline
\end{tabular}

$\mathrm{CO}$, maize without crude glycerine; CGM, crude glycerine replacing maize; CGSH, crude glycerine replacing soybean hulls; $\mathrm{T}$, time effect; $\mathrm{CL}$, concentrate level effect; $\mathrm{FR}$, feeding regime effect; $\mathrm{CL} \times \mathrm{FR}$, concentrate level and feeding regime interaction effect; $T \times C L \times F R$, interaction between time, concentrate level and feeding regime; $L M A$, longissimus muscle area; RFT, rib fat thickness. 
rumen, thus reducing the time available for microbial fermentation of the ingested feed and limiting methane production. Bulls fed LC diets and HC diets had similar methane emissions, which is likely to be due to the similar DMI levels for these diets.

In an in vivo study, Avila-Stagno et al. (2013) did not observe any effect of using CG to replace barley grain for 0.21 of diet DM on methane emissions from lambs; however, in an in vitro study Lee et al. (2011) observed that the inclusion of glycerol with maize or alfalfa reduced methane production after $24 \mathrm{~h}$. In the present in vivo study, it was expected that the inclusion of CG in the diets would reduce methane emissions because recent studies reported that glycerol fermentation favours propionate over acetate production (Wang et al. 2009; Avila et al. 2011). Glycerine failed to decrease methane emissions as hypothesized, but tended to increase it in HC diets.

Glycerine fermentation does not always produce a hydrogen sink because it promotes a shift in carbohydrate fermentation that may affect the overall electron balance in the rumen, and not promote reduction in the availability of hydrogen for methane formation. Glycerol is a more reduced substrate than sugars and releases two electron pairs for each mole of glycerol converted to pyruvate (Zhang \& Yang 2009); one in the oxidation of glycerol to dihydroxyacetone, which is then phosphorylated and enters glycolysis, and the other in glycolysis itself, in the oxidation of 3-phosphoglyceraldehyde to 3-phosphoglycerate (Biebl et al. 1999). Thus, according to AvilaStagno et al. (2014), this compensates for electron incorporation in the conversion of pyruvate or phosphoenolpyruvate to propionate and there is no net electron incorporation in the conversion of glycerol to propionate. Furthermore, Avila-Stagno et al. (2014) reported that there is a linear increase in butyrate production when glycerol constitutes up to $0 \cdot 15$ of DM, thus, butyrate production from both carbohydrates and glycerol would result in a release of reducing equivalents and contribute to increasing methane emissions.

Increasing the starch content of the diet shifts rumen fermentation towards propionic acid production at the expense of acetic acid (McGeough et al. 2010). The production of propionic acid is a hydrogen-utilizing process, which deprives the methanogenic bacteria of the hydrogen necessary to produce methane (Moss et al. 2000). This suggests that a dietary starch threshold must be achieved to sufficiently stimulate glucogenic VOLATILE FATTY ACID production to a concentration that could provide a viable hydrogen sink alternative to methanogenesis (Lovett et al. 2005), thus reducing methane emissions.

It was hypothesized that bulls fed CG as a replacement for fibre-based energy ingredients in LC diets would emit less methane than bulls fed starch-based ingredients in $\mathrm{HC}$ diets (with or without CG) because CG might produce propionate more efficiently in LC diets with lower starch concentrations. The addition of glycerol plus forage (alfalfa) reduced the acetate : propionate ratio more than glycerol plus maize (Lee et al. 2011) in an in vitro study. Bulls fed CG as a replacement for soybean hulls in LC diets might use glycerol more efficiently for propionate production in the rumen, because these bulls had similar methane emissions (g/bull/day/kg DMl) to bulls fed HC diets without CG. Furthermore, they had a tendency to reduce methane emissions (g/bull/day/kg DMl) compared with bulls fed CG as a replacement for soybean hulls in $\mathrm{HC}$ diets.

The method used in the current study to quantify methane emissions has been debated in a number of studies (Pinares-Patiño et al. 2008, 2011). It has been carefully tested during the last two decades and some limitations have been described: maintaining a constant release rate from permeation tubes, effect of release rate upon emission rate of methane, background level determination, inconsistency between methane measurements determined in chambers and with $\mathrm{SF}_{6}$ and within and between animal variation. The technique is still new and further investigation can hopefully improve the technique (Storm et al. 2012).

Animal growth directly correlates with tissue growth, as it is dependent upon the rate and extent of cellular hypertrophy and hyperplasia comprising the respective tissues. Cellular enlargement occurs due to nutrient uptake by the cell and the balance between the anabolic and catabolic processes that regulate accretion of cellular components and structural materials (Etherton 1982). The current findings demonstrate that the bulls evaluated in the present work had similar glucose uptake in peripheral tissue and did not exhibit significant differences in growth. Likewise, Lage et al. (2012) did not observe differences in the LMA or RFT from the carcasses of bulls fed with LC or HC diets.

The change in live weight is an imprecise growth indicator, considering accretion of protein and fat tissue (Owens et al. 1995). McLeod \& Baldwin (2000) reported that digestive tract mass increases 
significantly when ruminants are fed fibre-based diets. When higher fibre levels are fed throughout the finishing period, the percentage of weight as gastrointestinal fill may not decrease (Buckley et al. 1990), thus explaining the similar ADG compared with bulls fed other diets, and the tendency to reduce the carcass deposition.

Glucose is derived from ruminal (Schoonmaker et al. 2003) and post-ruminal (Huntington et al. 2006) starch digestion. In contrast to maize, soybean hulls are low-starch energy supplements that are high in digestible fibre (Sharman et al. 2013). Starch fermentation in the rumen yields more propionate, less acetate and more glucose to the animal compared with fibre digestion (Church 1988). An increased supply of glucose from intestinal digestion of starch promotes lipogenesis via the citrate cleavage pathway; as such, lipogenesis in the total body could thus be enhanced (Owens et al. 1995). Therefore, intestinal fat synthesis could explain why an increased supply of intestinal starch often enhances the efficiency of finishing cattle (Owens et al. 1986). This effect may have been enhanced by the inclusion of CG in the diet because of the gluconeogenic property of this by-product.

Glycerine levels of up to $0 \cdot 10$ of the DM as a replacement for rapidly fermentable starch in feed for bulls finished in feedlots did not affect glucose serum concentrations (Bartoň et al. 2013). The increase in serum glucose in bulls fed CG as a replacement for soybean hulls was likely to be caused by the suppressed microbial fermentation activity induced by fasting and ruminal transit (Cole \& Hutcheson 1981, 1985). The soybean hulls exhibit a greater ruminal rate and degradation extent than maize (Ipharraguerre \& Clark 2003), so the reduction in microbial fermentation activity could have increased the non-degradable protein intake to the small intestine, and thus increased the amount of gluconeogenic precursors available and intestinal glucose absorption (Mueller et al. 2011).

It was hypothesized that bulls fed CGSH diets would improve their energy efficiency and obtain greater tissue deposition because Schroder \& Sudekum (1999) suggested that the energetic value of CG when fed in conjunction with a high-starch concentrate diet ( 0.60 concentrate) was approximately 0.85 of its value when fed with a low-starch concentrate diet. The results obtained with bulls fed fibrebased energy ingredients had smaller LMA than bulls fed diets with or without CG as a replacement for maize. This can be attributed to the greater serum glucose concentrations of bulls fed diets with CGSH, thus lower glucose uptake by tissues and less lean tissue development. Bulls fed diets with maize received a more than adequate supply of glucose from dietary sources, suggesting that ruminal starch fermentation to provide other nutrient needs (energy substrates, amino acids) would improve the efficiency of starch use for growth (Huntington 1997).

Soybean hulls are low in lignin and composed of a large proportion of potentially digestible fibre (Quicke et al. 1959; Hsu et al. 1987). Therefore, when soybean hulls are fermented in the rumen, more acetate than propionate is produced. The contribution of acetate to lipogenesis is greatest in subcutaneous adipose tissue (Smith \& Crouse 1984; Smith et al. 2009). Likewise, Sharman et al. (2013) reported no differences in subcutaneous fat from carcasses of animals fed fibre-based supplements (soybean hulls) compared with carcasses of animals fed starch-based supplements (maize). However, differences in mRNA expressions of genes involved in lipogenesis as a fatty acid synthase (FASN), adipocyte fatty acid binding protein 4 (FABP4) and stearoyl-CoA desaturase 1 ( $\Delta 9$-desaturase) were detected in perirenal adipose tissue of growing Angus steers fed fibrebased supplements (soybean hulls) in comparison with expression of genes in the perirenal adipose tissue from animals fed starch-based supplements (maize). This explains why bulls fed CGSH in the current work, despite a lower CrG and LMA, had similar thickness of subcutaneous fat.

\section{CONCLUSIONS}

Increasing concentrate content $(0 \cdot 40-0 \cdot 60)$ did not affect the intake, methane emissions, or growth performance. Bulls fed CG as a replacement for soybean hulls in LC diets had similar methane emissions (g/kg DMI) compared with bulls fed starchbased ingredients in $\mathrm{HC}$ diets with or without CG. Furthermore, the inclusion of CG as a replacement for soybean hulls in LC diets tended to decrease the methane emissions more than those in bulls fed CG as a replacement for soybean hulls in HC diets. However, when CG replaces soybean hulls in the diet, it does not compromise the DMI or ADG, but animal growth is compromised, decreasing $\mathrm{CrG}$, feed efficiency in relation to $\mathrm{CrG}$, and lean tissue in relation bulls fed CG as a replacement for maize in the diets. 
We thank the São Paulo Research Foundation (FAPESP) for funding this research and Trouw Nutrition Brazil/Bellman (São Paulo, Brazil) for providing feed supplies for experimental diets.

\section{REFERENCES}

Abo El-Nor, S., Abughazaleh, A. A., Potu, R. B., Hastings, D. \& KнатTAB, M. S. A. (2010). Effects of differing levels of glycerol on rumen fermentation and bacteria. Animal Feed Science and Technology 162, 99-105.

AOAC (1990). Official Methods of Analysis, 15th edn, Arlington, Virginia, USA: Association of Official Analytical Chemists.

Avila, J. S., Chaves, A. V., Hernandez-Calva, M., Beauchemin, K. A., McGinN, S.M., Wang, Y., Hasrtard, O.M. \& McAluister, T.A. (2011). Effects of replacing barley grain in feedlot diets with increasing levels of glycerol on in vitro fermentation and methane production. Animal Feed Science and Technology 166-167, 265-268.

Avila-Stagno, J., Chaves, A. V., He, M. L., Harstad, O. M., Beauchemin, K.A., McGinN, S. M. \& McAllister, T.A. (2013). Effects of increasing concentrations of glycerol in concentrate diets on nutrient digestibility, methane emissions, growth, fatty acid profiles and carcass traits of lambs. Journal of Animal Science 91, 829-837.

Avila-Stagno, J., Chaves, A. V., Ribeiro Júnior, G. O., Ungerfeld, E. M. \& McAllister, T. A. (2014). Inclusion of glycerol in forage diets increases methane production in a rumen simulation technique system. British Journal of Nutrition 111, 829-835.

Bartoñ, L., Bureš, D., Homolka, P., Jančí́, F., Marounek, M. \& ŘEHÁK, D. (2013). Effects of long-term feeding of crude glycerin on performance, carcass traits, meat quality, and blood and rumen metabolites of finishing bulls. Livestock Science 155, 53-59.

Biebl, H., Menzel, K., Zeng, A. P. \& Deckwer, W. D. (1999). Microbial production of 1,3-propanediol. Applied Microbiology and Biotechnology 52, 289-297.

BRAZIL (1997). Ministério da agricultura, Pecuária e Abastecimento, Regulamento da Inspeção Industrial e Sanitária de Produtos de Origem Animal [Food of Animal Origin Sanitary and Industry Inspection]. Brasília: Ministério da Agricultura, Pecuária e Abastecimento. In Portuguese.

Buckley, B. A., Baker, J. F., Dickerson, G. E. \& Jenkins, T. G. (1990). Body composition and tissue distribution from birth to 14 months for three biological types of beef heifers. Journal of Animal Science 68, 3109.

Church, D. C. (1988). The Ruminant Animal: Digestive Physiology and Nutrition. Englewood Cliffs, NJ: Prentice Hall.

Cole, N. A. \& HutCheson, D. P. (1981). Influence of beef steers of two sequential short periods of feed and water deprivation. Journal of Animal Science 53, 907-915.

Cole, N. A. \& Hutcheson, D. P. (1985). Influence of prefast feed intake on recovery from feed and water deprivation by beef steers. Journal of Animal Science 60, 772-780.
Drouillard, J. S. (2008). Glycerin as a feed for ruminants: using glycerin in high-concentrate diets. Journal of Animal Science 86 (Suppl. 2), 392. (Abstract).

Drouillard, J. S. (2012). Utilization of crude glycerin in beef cattle. In Biofuel Co-products as Livestock Feed Opportunities and Challenges (Ed. H. P. S. Makkar), pp. 155-161. Rome, Italy: FAO.

EtHeRTON, T. D. (1982). The role of insulin-receptor in interactions in regulation of nutrient utilization by skeletal muscle and adipose tissue; a review. Journal of Animal Science 54, 58-67.

Forbes, J. M. (2007). A personal view of how ruminant animals control their intake and choice of food: minimal total discomfort. Nutrition Research Reviews 20, 132-146.

Greiner, S. P., Rouse, G. H., Wilson, D. E., Cundiff, L. V. \& WheELER, T.L. (2003). The relationship between ultrasound measurements and carcass fat thickness and longissimus muscle area in beef cattle. Journal of Animal Science 81, 676-682.

Holtshausen, L., Schwartzkopf-Genswein, K.S. \& Beauchemin, K.A. (2013). Ruminal pH profile and feeding behaviour of feedlot cattle transitioning from a high-forage to a high-concentrate diet. Canadian Journal of Animal Science 93, 529-533.

Hsu, J. T., Faulkner, D. B., Garleb, K. A., Barclay, R. A., FAHEY, G. C., Jr. \& Berger, L. L. (1987). Evaluation of corn fiber, cottonseed hulls, oat hulls, and soybean hulls as roughage sources for ruminants. Journal of Animal Science 65, 244-255.

Huntington, G. B. (1997). Starch utilization by ruminants: from basics to the bunk. Journal of Animal Science 75, 852-867.

Huntington, G. B., Harmon, D. L. \& Richards, C. J. (2006). Sites, rates, and limits of starch digestion and glucose metabolism in growing cattle. Journal of Animal Science $\mathbf{8 4}$ (E-Suppl.), E14-E24.

IPHARRAGUeRRE, I. R. \& ClaRK, J. H. (2003). Soyhulls as an alternative feed for lactating dairy cows: a review. Journal of Dairy Science 86, 1052-1073.

Johnson, K. A. \& Johnson, D. E. (1995). Methane emissions from cattle. Journal of Animal Science 73, 2483-2492.

Johnson, K. A., Huyler, M., Westburg, H., Lamb, B. \& ZIMMERMAN, P. (1994). Measurement of methane emissions from ruminant livestock using a SF6 tracer technique. Environmental Science \& Technology 28, 359-362.

Lage, J. F., Paulino, P. V. R., Valadares Filho, S. C., Souza, E. J. O., Duarte, M.S., Benedetı, P.D. B., Souza, N. K. P. \& Cox, R. B. (2012). Influence of genetic type and level of concentrate in the finishing diet on carcass and meat quality traits in beef heifers. Meat Science 90, 770-774.

Lee, S. Y., Lee, S. M., Cho, Y. B., Kam, D. K., Lee, S. C., Kim, C. H. \& SeO, S. (2011). Glycerol as a feed supplement for ruminants: In vitro fermentation characteristics and methane production. Animal Feed Science and Technology 166-167, 269-274.

Lovett, D. K., Stack, L. J., Lovell, S., Callan, J., Flynn, B., HaWkins, M. \& O'MARA, F.P. (2005). Manipulating enteric methane emissions and animal performance of late-lactation dairy cows through concentrate supplementation at pasture. Journal of Dairy Science 88, 2836-2842. 
McGeough, E. J., O’Kiely, P., Hart, K. J., Moloney, A.P., Boland, T. M. \& KenNy, D. A. (2010). Methane emissions, feed intake, performance, digestibility, and rumen fermentation of finishing beef cattle offered whole-crop wheat silages differing in grain content. Journal of Animal Science 88, 2703-2716.

McLeOD, K. R. \& BALDWIN, R. L. (2000). Effects of diet forage: concentrate ratio and metabolizable energy intake on visceral organ growth and in vitro oxidative capacity of gut tissues in sheep. Journal of Animal Science 78, 760-770.

MERTENS, D. R. (1997). Creating a system for meeting the fiber requirements of dairy cows. Journal of Dairy Science $\mathbf{8 0}$, 1463-1481.

Mitsumori, M. \& Sun, W. (2008). Control of rumen microbial fermentation for mitigating methane emissions from the rumen. Journal of Animal Science 21, 144-154.

Moss, A. R., Jouany, J. P. \& Newbold, J. (2000). Methane production by ruminants: its contribution to global warming. Annales De Zootechnie 49, 231-253.

Mueller, C. J., Blalock, H. M. \& Pritchard, R. H. (2011). Use of soybean hulls as a replacement for dry rolled corn in beef cattle feedlot receiving diets. Journal of Animal Science 89, 4142-4150.

OWENS, F. N., ZINN, R. A. \& KIM, Y. K. (1986). Limits to starch digestion in the ruminant small intestine. Journal of Animal Science 63, 1634-1648.

Owens, F. N., Gill, D. R., Secrist, D. S. \& Coleman, S. W. (1995). Review of some aspects of growth and development of feedlot cattle. Journal of Animal Science 73, 3152-3172.

Parsons, G. L., Shelor, M. K. \& Drouillard, J. S. (2009). Performance and carcass traits of finishing heifers fed crude glycerin. Journal of Animal Science 87, 653-657.

Pina, D.S., Valadares Filho, S.C., Tedeschl, L. O., Barbosa, A. M. \& Valadares, R. F. D. (2009). Influence of different levels of concentrate and ruminally undegraded protein on digestive variables in beef heifers. Journal of Animal Science 87, 1058-1067.

Pinares-Patiño, C.S., Holmes, C. W., Lassey, K. R. \& Ulyatt, M. J. (2008). Measurement of methane emission from sheep by the sulphur hexafluoride tracer technique and by the calorimetric chamber: failure and success. Animal 2, 141-148.

Pinares-Patiño, C. S., Lassey, K. R., Martin, R. J., Molano, G., Fernandez, M., Maclean, S., Sandoval, E., Luo, D. \& CLARK, H. (2011). Assessment of the sulphur hexafluoride (SF6) tracer technique using respiration chambers for estimation of methane emissions from sheep. Animal Feed Science and Technology 166-167, 201-209.

Pyatt, N. A., Doane, P. H. \& Cecava, M. J. (2007). Effect of crude glycerin in finishing cattle diets. Journal of Animal Science 85 (Suppl.), E409-E412.

Quicke, B. V., Bentley, O. G., Scott, H. W., Johnson, R. R. \& Moxon, A. L. (1959). Digestibility of soybean hulls and flakes and the in vitro digestibility of cellulose in various milling by-products. Journal of Dairy Science 42, 185-186.

Ramos, M. H. \& Kerley, M. S. (2012). Effect of dietary crude glycerol level on ruminal fermentation in continuous culture and growth performance of beef calves. Journal of Animal Science 90, 892-899.
Roger, V., Fonty, G., Andre, C. \& Gouet, P. (1992). Effects of glycerol on the growth, adhesion, and cellulolytic activity of rumen cellulolytic bacteria and anaerobic fungi. Current Microbiology 25, 197-196.

Schoonmaker, J.P., Cecava, M. J., Faulkner, D. B., Fluharty, F. L., Zerby, H. N. \& Loerch, S. C. (2003). Effect of source of energy and rate of growth on performance, carcass characteristics, ruminal fermentation, and serum glucose and insulin of early-weaned steers. Journal of Animal Science 81, 843-855.

Schroder, A. \& SudeKum, K. H. (1999). Glycerol as a byproduct of biodiesel production in diets of ruminants. In 10th International Rapeseed Congress (Eds N. Wratten \& P. W. Salisbury), article number 241. Canberra, Australia, The Regional Institute. Available from: http://www.regional. org.au/au/gcirc/1/241.htm\#TopOfPage (verified 18 February 2016).

Sharman, E. D., Lancaster, P. A., Krehbiel, C. R., Hilton, G. G., Stein, D. R., Desilva, U. \& Horn, G.W. (2013). Effects of starch- vs. fiber-based energy supplements during winter grazing on partitioning of fat among depots and adipose tissue gene expression in growing cattle and final carcass characteristics. Journal of Animal Science 93, 2264-2277.

SMITH, S. B. \& Crouse, J. D. (1984). Relative contributions of acetate, lactate and glucose to lipogenesis in bovine intramuscular and subcutaneous adipose tissue. Journal of Nutrition 114, 792-800.

Smith, S. B., KaWachi, H., ChOl, C. B., ChOl, C. W., Wu, G. \& SAWYER, J. E. (2009). Cellular regulation of bovine intramuscular adipose tissue development and composition. Journal of Animal Science 8, 72-82.

Storm, I. M. L., Hellwing, A. L. F., Nielsen, N. I. \& Madsen, J. (2012). Methods for measuring and estimating methane emission from ruminants. Animal 2, 160-183.

Valadares Filho, S. C., Paulino, P. V. R. \& Magalhães, K. A. (2006). Exigências nutricionais de zebuínos e tabelas de composição de alimentos - BR CORTE. 1st edn, Viçosa, Brazil: UFV, Suprema Gráfica Ltda.

Van Soest, P.J., Robertson, J. B. \& Lewis, B. A. (1991). Methods for dietary fiber, and nonstarch polyssacarides in relations to animal nutrition. Journal of Dairy Science 74, 3583-3597.

Wang, C., LuI, Q., Huo, W. J., Yang, W. Z., Dong, K. H., HuANG, X. Y. \& GuO, G. (2009). Effects of feeding glycerol on rumen fermentation, urinary excretion of purine derivatives and feed digestibility in steers. Livestock Science 121, 15-20.

Westberg, H.H., Johnson, K. A., Cossalman, M. W. \& Michal, J. J. (1998). A SF6 Tracer Technique: Methane Measurement from Ruminants, 2nd edn, Pullman, Washington, USA: Washington State University.

Yan, T., Agnew, R. E., Gordon, F. J. \& Porter, M. G. (2000). Prediction of methane energy output in dairy and beef cattle offered grass silage-based diets. Livestock Production Science 64, 253-263.

ZhANG, A. \& YANG, S. T. (2009). Propionic acid production from glycerol by metabolically engineered Propionibacterium acidipropionici. Process Biochemistry 44, 13461351. 